NENAD RISTIĆ, GORDANA TOPLIČIĆ-ĆURČIĆ*, DUŠAN GRDIĆ

University of Niš, Faculty of Civil Engineering and Architecture, Niš, Serbia
Scientific paper

ISSN 0351-9465, E-ISSN 2466-2585

UDC:620.178.16:666.98

doi:10.5937/ZasMat1504435R

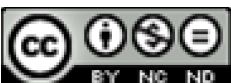

Zastita Materijala $56(4)$

435 - 445 (2015)

\title{
Abrasion resistance of concrete made with micro fibers and recycled granulated rubber
}

\begin{abstract}
Durability of concrete engineering structures in most part depends on the resistance of their surface to mechanical abrasion. The paper presents the results of experimental test of performance of concretes made with micro fibers and recycled granulated rubber in fresh and hardened state, as well as the comparative analysis of wear grinding resistance and hydroabrasive resistance of concrete. Six batches of concrete were made for the tests: reference concrete, concrete with partial replacement of fine river aggregate with recycled granulated rubber, two batches with the addition of polypropylene fibers (monofilament and fibrillated) and two batches of concrete with addition of steel hook ended fibers (short - having length $30 \mathrm{~mm}$ and long - having length $50 \mathrm{~mm}$ ). It was found that the addition of micro-reinforcement or recycled rubber contributes to the increase of concrete wear grinding resistance and hydro-abrasive resistance. There is a difference in the abrasive resistance depending on test method.
\end{abstract}

Keywords: concrete, recycled granulated rubber, polypropylene fibers, steel fibers, wear grinding resistance, hydro-abrasive resistance.

\section{INTRODUCTION}

Abrasion of concrete occurs due to scraping, rubbing, skidding or sliding of objects on its surface. The abrasion resistance of concrete is influenced by number of factors such as compressive strength, surfacing finish, aggregate properties, types of hardeners, and curing. A number of previous studies [1-3] have indicated that wear resistance of concrete is primarily dependent on the compressive strength of concrete. Therefore, airentrainment, water-cement ratio, and types of aggregates and their properties, which have influence on compressive strength of concrete, should also have their effect on the wear resistance of concrete. In general, hardened paste has low wear resistance. To develop concrete for high wear resistance, it is important to use hard surface aggregates, surface materials, and paste having low porosity and high strength [2].

${ }^{*}$ Corresponding author: G.Toplicic-Curicic

E-mail: gordana.toplicic.curcic@gaf.ni.ac.rs

Paper received: 13. 06. 2015.

Paper accepted: 19. 08. 2015.

Paper is available on the website: www.idk.org.rs/casopis
Resistance of concrete to abrasive action, apart from the composition of the concrete mixture, also depends on the external conditions to which concrete is exposed. The research by various authors demonstrated that the concretes produced with various mineral admixtures (silica powder, fly ash, blast furnace slag, milled basalt) [4-8], addition of still fibers [9-12], addition of polypropylene fibers [13-14] or with aluminate cements, high strength concretes, rolled concretes and addition of recycled granulated rubber [15-16] have to a lesser or larger extent a better abrasive resistance in comparison to the reference concrete produced without any admixtures, with the common Portland cement.

Concrete which is used for constructing structures that are exposed to wear, apart from having good mechanical properties must also be resistant to abrasion. Many tests showed that the mechanical characteristics of concrete can be used to predict its hydro-abrasive resistance. Siddique and Khatib , Yen et al., Lui Y.W. et al. [6,17-18] showed that there is a correlation between the abrasive resistance of concrete and compressive strength and flexural strength. Šušterčič in his paper [16] showed that the concrete with $9.5 \%$ of replacement granulated rubber instead of fine river 
aggregate, has a better hydro-abrasive strength in comparison to the reference concrete with no added rubber. He also showed that there is a strong connection between hydro-abrasive resistance of concrete on one hand and compressive strength, modulus of elasticity and wear resistance by Böhme, on the other. Yazici and Inan [19] developed a relationship between mechanical properties (compressive and splitting tensile strengths) and wear resistance of high strength concretes. They concluded that wear damage of high strength concrete can be estimated from compressive and splitting tensile strength results. The proposed equation has a sufficient reliability.

The addition of steel fibers may contribute significantly to increase the abrasion resistance of concrete. Test results of research [20] indicated that abrasion resistance and mechanical properties can be improved by incorporating steel micro-fiber. The positive effect of fibers can be enhanced by reducing W/C ratio. However, the steel fibers not always improve the erosion resistance of the concrete in the hydraulic structures. In the case of the action of the rubble dragged by water at the speed lower than $10 \mathrm{~m} / \mathrm{s}$, the increased wear of the steel fibers reinforced concrete has been observed, as compared to the concrete without fibers [21]. The investigations [21-23] of the erosion of the concretes at the low speed of the abrasive mixture have showed that the addition of the steel fibers of the lowaspect ratio $(\lambda \leq 50)$ does not influence the abrasion resistance of the high performance concretes, and even causes the downfall of their resistance comparing to the concrete without the fibers [24-25].

Besides the steel fibers, the synthetic fibers are now often used in the concrete structures (particularly in the surface layers). Using of the synthetic fibers increases the resistance of the concrete to the cracking at bending, improves its impact resistance, fatigue resistance, corrosion resistance and resistance to temperature shock. The polypropylene and carbon fibers increase the erosion resistance [26-28] and cavitation resistance [29-30] of the concrete. When designing the hydraulic concrete, not only the material factors, but also the mechanism of wearing of the concrete surface in the structure should be taken into consideration regarding to the selection of the additives (including various fibers) for improving the erosion resistance of the concrete. In practice, the cavitation and water-dragged rubble action are often generally categorized as abrasive-type actions. However, the mechanism of deterioration of the concrete surface is different in both cases.

This paper researches the influence of reinforcement of concrete with polypropylene and steel fibers and replacement of fine river aggregate with recycled granulated rubber on abrasive resistance, tested by two methods: the Böhme device method, and water/sand mixture jet wear method.

\section{DETAIL OF THE EXPERIMENT}

\subsection{Materials used in the experiment}

The reference concrete was produced with the Portland cement CEM I $42.5 \mathrm{R}$, whose properties are presented in the table 1.

Table 1 - Physico-mechanical properties of cement

\begin{tabular}{|l|c|}
\hline \multicolumn{1}{|c|}{ Property of cement } & Value \\
\hline Stetting time, min & $\begin{array}{c}\text { start } 135 \\
\text { end } 160\end{array}$ \\
\hline $\begin{array}{l}\text { Mill fineness - } \\
\text { sieve residue } 0.09 \mathrm{~mm}\end{array}$ & $3.2 \%$ \\
\hline Density & $3000 \mathrm{~kg} / \mathrm{m}^{3}$ \\
\hline Loose material bulk density & $925 \mathrm{~kg} / \mathrm{m}^{3}$ \\
\hline Compacted material bulk density & $1521 \mathrm{~kg} / \mathrm{m}^{3}$ \\
\hline Bending strength after 2 days & $5.99 \mathrm{~N} / \mathrm{mm}^{2}$ \\
\hline Bending strength after 28 days & $7.21 \mathrm{~N} / \mathrm{mm}^{2}$ \\
\hline Compressive strength after 2 days & $33.67 \mathrm{~N} / \mathrm{mm}^{2}$ \\
\hline Compressive strength after 28 days & $54.21 \mathrm{~N} / \mathrm{mm}^{2}$ \\
\hline
\end{tabular}

For preparation of concrete was used the aggregate obtained by mixing three fractions $0 / 4$, $4 / 8$ and $8 / 16 \mathrm{~mm}$ from the river aggregate of the Southern Morava River. Particle size distribution of the individual fractions and used aggregate mixtures is presented in the figure 1.

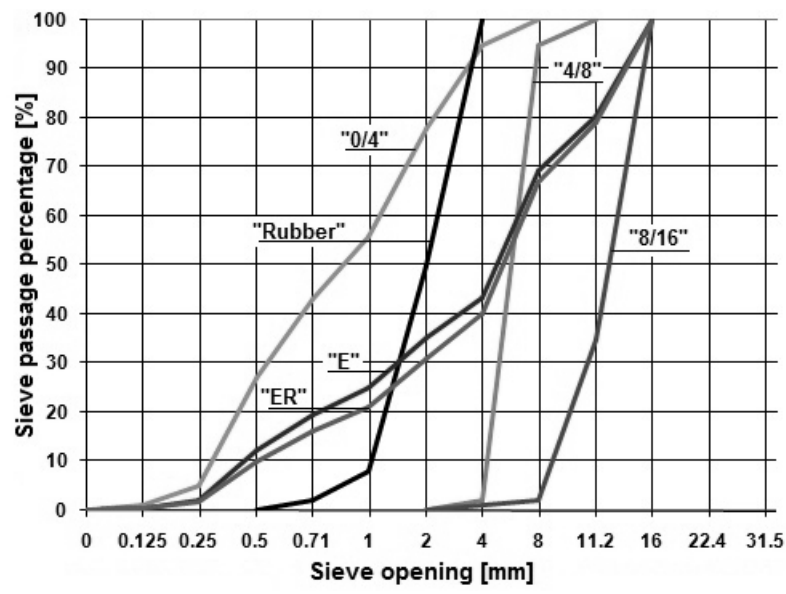

Figure 1 - Particle size distribution of the individual fractions and used aggregate mixtures

Four types of fibers were used for production of micro-reinforced concretes: polypropylene fibers FIBRILs S120 and FIBRILs F120 produced by "Motvoz" Grosuplje from Slovenia, steel fibers ZS/N $0.5 \times 30 \mathrm{~mm}$ and $Z S / N 1.05 \times 50 \mathrm{~mm}$, produced by "Spajic" d.o.o. Company Negotin from Serbia. The steel ZS/N $0.5 \times 30 \mathrm{~mm}$ and ZS/N $1.05 \times 50 \mathrm{~mm}$ fibers belong to the group of hook ended fibers, while the polypropylene fibers of FIBRILs S120 
type belong to the group of monofilament fibers of circular cross sections and smooth surface and the polypropylene fibers of FIBRILs F120 type belong to the group of fibrillated fibers of rectangle cross sections and smooth surface, figure 2 .
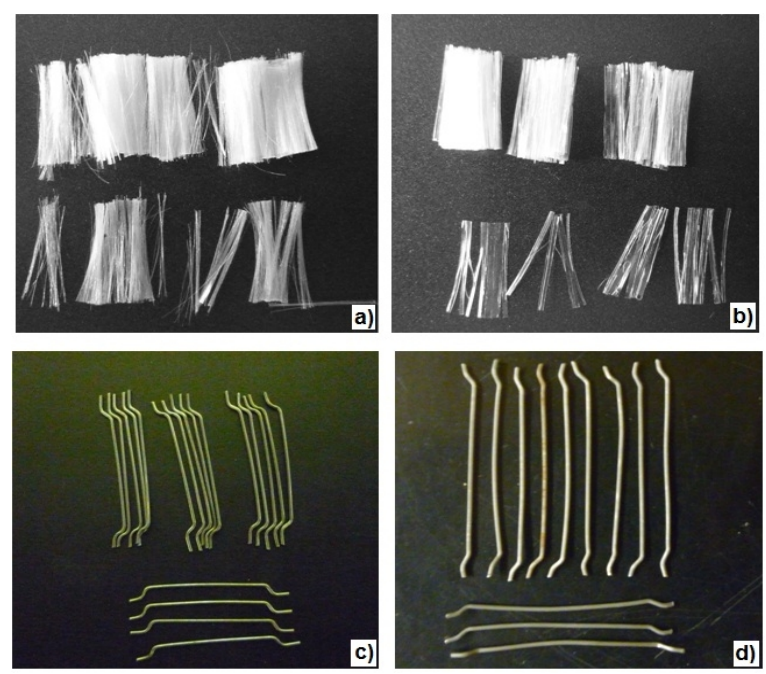

Figure 2 - The fibers used for reinforcing concrete:

a) FIBRILs S120, b) FIBRILs F120, c) ZS/N

$0.5 \times 30 \mathrm{~mm}$ and d) ZS/N $1.05 \times 50 \mathrm{~mm}$
The used recycled rubber was a 0.5 - $4 \mathrm{~mm}$ fraction, figure 3. Particle density and bulk density of rubber aggregate in the loose state were determined according to SRPS ISO 6783:1999 and SRPS ISO $6782: 1999$ and they amounted to $1150 \mathrm{~kg} / \mathrm{m}^{3}$ and $480 \mathrm{~kg} / \mathrm{m}^{3}$, respectively. Particle size distribution of granulated recycled rubber is presented in figure 1. Also used was superplasticizing water reducer Sika ViscoCrete 3070 . The fibers characteristics are given in the table 2 .

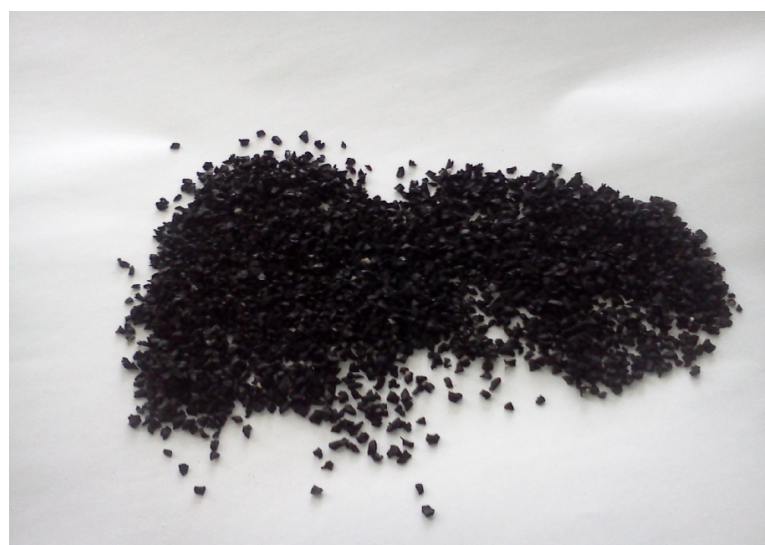

Figure 3-Recycled rubber used for examination

Table 2 - Characteristics of polypropylene and steel fibers

\begin{tabular}{|l|c|c|c|c|}
\hline & \multicolumn{2}{|c|}{ Polypropylene fibers } & \multicolumn{2}{c|}{ Steel fibers } \\
\hline \multicolumn{1}{|c|}{ Characteristic } & $\begin{array}{c}\text { FIBRILs S120 } \\
\text { (monofilament fibers) }\end{array}$ & $\begin{array}{c}\text { FIBRILs F120 } \\
\text { (fibrillated fibers) }\end{array}$ & $\begin{array}{c}\text { ZS/N 0.5x30 mm } \\
\text { (hook ended fibers) }\end{array}$ & $\begin{array}{c}\text { ZS/N 1.05x50mm } \\
\text { (hook ended fibers) }\end{array}$ \\
\hline Fiber length & $12 \mathrm{~mm}$ & $12 \mathrm{~mm}$ & $30 \mathrm{~mm}$ & $50 \mathrm{~mm}$ \\
\hline $\begin{array}{l}\text { Diameter } \\
\text { (equivalent) }\end{array}$ & $0.037 \mathrm{~mm}$ & $0.45 \mathrm{~mm}$ & $0.50 \mathrm{~mm}$ & $1.05 \mathrm{~mm}$ \\
\hline Aspect ratio & 324 & 27 & 60 & 48 \\
\hline Tensile strength & $300,7 \pm 31,7 \mathrm{~N} / \mathrm{mm}^{2}$ & $274,0 \pm 26,9 \mathrm{~N} / \mathrm{mm}^{2}$ & $1100 \pm 165 \mathrm{~N} / \mathrm{mm}^{2}$ & $1100 \pm 165 \mathrm{~N} / \mathrm{mm}^{2}$ \\
\hline
\end{tabular}

Table 3 - Composition of $1 \mathrm{~m}^{3}$ of concrete mixtures used in the experiment

\begin{tabular}{|c|c|c|c|c|c|c|c|c|c|c|c|}
\hline \multirow{3}{*}{$\begin{array}{l}\text { Series of } \\
\text { specimen }\end{array}$} & \multicolumn{3}{|c|}{ Aggregate } & \multirow{2}{*}{ Rubber } & \multirow{2}{*}{ Cement } & \multirow{2}{*}{ Water } & \multirow{2}{*}{$\begin{array}{c}\text { Sika VSC } \\
3070\end{array}$} & \multicolumn{2}{|c|}{$\begin{array}{l}\text { Polypropylene } \\
\text { fibers }\end{array}$} & \multicolumn{2}{|c|}{ Steel fibers } \\
\hline & $0 / 4 \mathrm{~mm}$ & $4 / 8 \mathrm{~mm}$ & $8 / 16 \mathrm{~mm}$ & & & & & $\begin{array}{l}\text { Fibrils } \\
\text { S } 120\end{array}$ & $\begin{array}{l}\text { Fibrils } \\
\text { F } 120\end{array}$ & $\begin{array}{c}Z S / N \\
0.5 \times 30\end{array}$ & $\begin{array}{c}Z S / N \\
1.05 \times 50\end{array}$ \\
\hline & $\mathrm{kg} / \mathrm{m}^{3}$ & $\mathrm{~kg} / \mathrm{m}^{3}$ & $\mathrm{~kg} / \mathrm{m}^{3}$ & $\mathrm{~kg} / \mathrm{m}^{3}$ & $\mathrm{~kg} / \mathrm{m}^{3}$ & $\mathrm{~kg} / \mathrm{m}^{3}$ & $\mathrm{~kg} / \mathrm{m}^{3}$ & $\mathrm{~kg} / \mathrm{m}^{3}$ & $\mathrm{~kg} / \mathrm{m}^{3}$ & $\mathrm{~kg} / \mathrm{m}^{3}$ & $\mathrm{~kg} / \mathrm{m}^{3}$ \\
\hline$E$ & 806 & 447 & 537 & - & 400 & 177,6 & 2,40 & - & - & - & - \\
\hline ER & 631 & 449 & 540 & 78 & 404 & 178,8 & 3,03 & - & - & - & - \\
\hline EPM & 806 & 447 & 537 & - & 400 & 177,4 & 2,60 & 0,91 & - & - & - \\
\hline EPF & 808 & 448 & 538 & - & 401 & 177,9 & 2,60 & - & 0,91 & - & - \\
\hline ESS & 803 & 446 & 536 & - & 399 & 176,8 & 2,80 & - & - & 25,0 & - \\
\hline ESL & 801 & 445 & 534 & - & 398 & 176,3 & 2,80 & - & - & & 25,0 \\
\hline
\end{tabular}

\subsection{Concrete mixture composition}

Six mixtures for testing fresh and hardened concrete properties were made. The reference mixture was made by the river aggregate, cement, water and water reducer, marked with $E$. The mixture marked ER was made with $10 \%$ of rubber substitute instead of the river aggregate. The aggregate substitution was performed by volume. The mixture marked with EPM was made with addition of polypropylene monofilament fibers 
FIBRILs S120, EPF with addition of polypropylene fibrillated fibers FIBRILs F120, ESS with addition of steel hook ended fibers ZS/N $0.5 \times 30 \mathrm{~mm}$ and ESL with addition of steel fibers with hook ended fibers $\mathrm{ZS} / \mathrm{N} 1.05 \times 50 \mathrm{~mm}$. Basic fractions of the river aggregate $0 / 4 \mathrm{~mm}, 4 / 8 \mathrm{~mm}$ and $8 / 16 \mathrm{~mm}$ were mixed in ratio $45 \%, 25 \%$ and $30 \%$. The particle size distribution of basic fractions of aggregates was the same for all the mixtures, with the minimum difference for those mixtures in which a part of fine river aggregate was replaced with recycled granulated rubber, figure 1 . The mixtures were made with the same water /cement ratio $\omega_{c}=0.45$ and with approximately same consistency of concrete (slump $90-110 \mathrm{~mm}$ ) which was achieved using superplasticizer. The compositions of the concrete mixtures are given in the table 3 .

\section{EXPERIMENTAL RESEARCH}

The scheme of the equipment for concrete abrasive resistance testing is displayed in the figure 4. Similar equipment was used by the researchers in Taiwan for testing of abrasive resistance of concrete $[5,18]$.

The equipment consists of a tin basin, with dimensions 2,0 $\times 2,0 \mathrm{~m}$ at the base and $1,5 \mathrm{~m}$ of height, whose front side is covered with a panel of transparent Plexiglas for visual observation during the tests. For the test, the basin is filled up to one third of its height with the mixture of water and sand, with granulation from $0.6 \mathrm{~mm}$ to $1.2 \mathrm{~mm}$, in the mass ratio of 10:1. The sand used as the abrasive for wearing concrete was silica sand. Four electrical motors turn the vanes making a homogenous mixture of water and sand, while the centrifugal pump which via an intake sucks in the mixture and then ejects it under pressure though a nozzle on the test concrete slab with the dimensions $200 \times 200 \times 50 \mathrm{~mm}$. The concrete slab is fitted onto the rig which can rotate around the horizontal axis and in this manner change the incidence angle of the jet and the examined specimen.
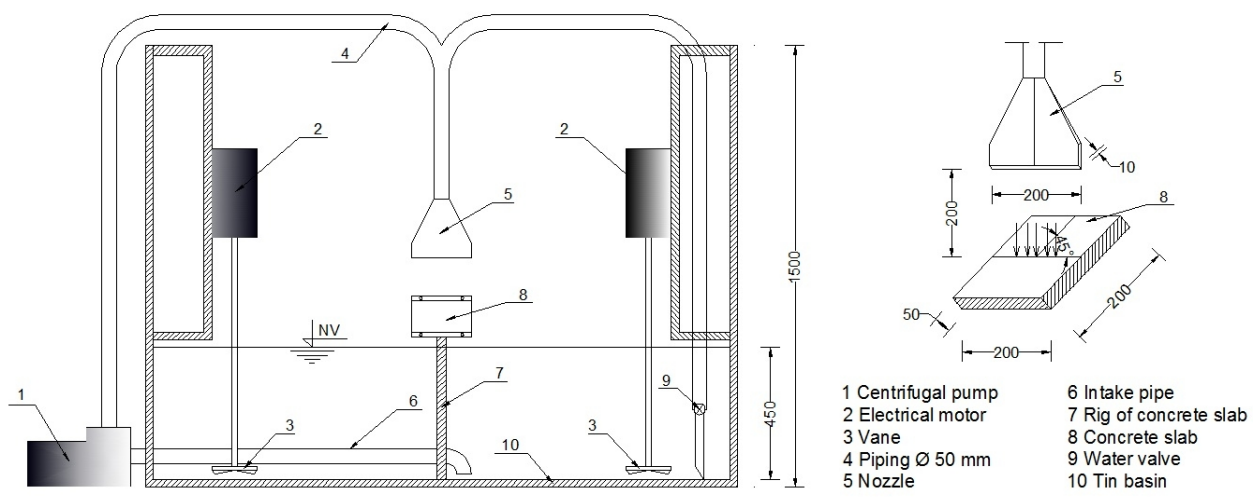

Figure 4-Scheme of equipment for testing abrasion of concrete

The test specimen, i.e. concrete slab, is first dried to the constant mass at $105 \pm 5{ }^{\circ} \mathrm{C}$ which is then measured $\left(m_{1}\right)$. The specimen is then saturated by water via the gradual immersion method and exposed to the action of the water/sand mixture jet for the period of 120 minutes. The water temperature during the test was $30^{\circ} \mathrm{C}$. Eventually, the specimen is again dried up to the constant mass and then the mass of abraded $\left(m_{2}\right)$ is measured. The accuracy of the specimen mass measurement is $\pm 0,1 \mathrm{~g}$. The water/sand mixture jet acts on the surface of concrete test slab at the angle of $45^{\circ}$ via the rectangular jet nozzle with dimensions of $10 \times 200 \mathrm{~mm}$. The nozzle jet velocity is $20 \mathrm{~m} / \mathrm{s}$, which is equivalent to the pressure of 2,4 bars, that is, 0,24 MPa. The difference of masses $\Delta \mathrm{m}$ is the mass of the material abraded under the action of the abrasive suspended in water.

The hydro-abrasion erosion rate $E_{R, m}$ by mass is calculated as:

$$
E_{R, m}=\frac{\Delta m}{t}=\frac{m_{1}-m_{2}}{t}[\mathrm{~g} / \mathrm{min}]
$$

where:

$m_{1}$ and $m_{2}$ - are the masses of the specimen dried up to the constant mass before and after the action of the mixture of water and the abrasive.

$t$ - time of action of the mixture on the test sample $(t=120 \mathrm{~min}$ ).

However, as the samples of hardened concrete have different densities depending on the percentage of granulated rubber used to substitute river aggregate, it is more suitable to use loss of sample volume due to the abrasive action for comparison, which is calculated by the following form

$$
\Delta V=\frac{\Delta m}{\gamma_{\text {hard,conc }}}\left[\mathrm{cm}^{3}\right],
$$


that is, the hydro-abrasion rate by volume

$$
E_{R, V}=\frac{\Delta V}{t}=\frac{\frac{m_{1}-m_{2}}{\gamma_{\text {hard,conc }}}}{t}\left[\mathrm{~cm}^{3} / \mathrm{min}\right],
$$

where:

$\gamma_{\text {hard,conc }}$ - density of hardened concrete, dried to the constant mass in $\mathrm{g} / \mathrm{cm}^{3}$.

The consistency was measured on the fresh concrete by the slump test according to SRPS ISO 4109:1997, the bulk density according to SRPS ISO 6276:1997 and air content of freshly mixed concrete according to SRPS ISO 4848:1999. The compressive strength and bulk density of hardened concrete were tested on the cubes with $150 \mathrm{~mm}$ sides according to SRPS ISO 4012:2000, the flexural strength on the prisms with dimensions 100 x $100 \times 400 \mathrm{~mm}$ according to SRPS ISO 4013: 2000, the tensile splitting strength on cylindrical cores $\varnothing 150 \times 300 \mathrm{~mm}$ according to SRPS ISO

4108:2000 and the wear grinding resistance on the cubes with $70.7 \mathrm{~mm}$ sides according to SRPS B.B8.015:1984. The age of the samples at the testing of hardened concrete properties was 90 days.

\section{RESULTS OF EXEPERIMENTAL RESEARCH}

The tests results of fresh and hardened concrete are presented in the tables 4,5 .

Table 4-Characteristics of concrete in fresh state

\begin{tabular}{|l|c|c|c|}
\hline $\begin{array}{c}\text { Series of } \\
\text { specimen }\end{array}$ & $\begin{array}{c}\text { Density } \\
{\left[\mathrm{kg} / \mathrm{m}^{3}\right]}\end{array}$ & Slump class & $\begin{array}{c}\text { Air content } \\
{[\%]}\end{array}$ \\
\hline E & 2370 & S3 $(110 \mathrm{~mm})$ & 3,1 \\
\hline ER & 2285 & S3 $(105 \mathrm{~mm})$ & 4,1 \\
\hline EPM & 2370 & S3 $(100 \mathrm{~mm})$ & 3,5 \\
\hline EPF & 2375 & S3 $(95 \mathrm{~mm})$ & 3,6 \\
\hline ESS & 2390 & S2 $(90 \mathrm{~mm})$ & 3,4 \\
\hline ESL & 2385 & S3 $(100 \mathrm{~mm})$ & 3,3 \\
\hline
\end{tabular}

Table 5 - Characteristics of concrete in hardened state

\begin{tabular}{|c|c|c|c|c|c|c|c|}
\hline \multirow{2}{*}{$\begin{array}{c}\text { Series of } \\
\text { specimen }\end{array}$} & $\begin{array}{c}\text { Density } \\
{\left[\mathrm{kg} / \mathrm{m}^{3}\right]}\end{array}$ & \multicolumn{2}{|c|}{$\begin{array}{c}\text { Compressive strength } \\
{[\mathrm{MPa}]}\end{array}$} & $\begin{array}{c}\text { Flexural } \\
\text { strength } \\
{[\mathrm{MPa}]}\end{array}$ & $\begin{array}{c}\text { Splitting } \\
\text { tensile } \\
\text { strength } \\
{[\mathrm{MPa}]}\end{array}$ & $\begin{array}{c}\text { Wear grinding } \\
{\left[\mathrm{cm}^{3} / 50 \mathrm{~cm}^{2}\right]}\end{array}$ & $\begin{array}{c}E_{R, V} \\
{\left[\mathrm{~cm}^{3} / \mathrm{min}^{3}\right.}\end{array}$ \\
\hline E & 2364 & 45,23 & 60,89 & 5,68 & 4,71 & 15,09 & 0,17813 \\
\hline ER & 2274 & 33,11 & 43,78 & 4,72 & 3,67 & 7,72 & 0,11844 \\
\hline EPM & 2364 & 45,56 & 63,23 & 6,04 & 5,36 & 13,73 & 0,15496 \\
\hline EPF & 2367 & 42,67 & 63,78 & 6,12 & 5,30 & 14,42 & 0,14749 \\
\hline ESS & 2380 & 44,11 & 64,11 & 6,22 & 5,44 & 13,86 & 0,17042 \\
\hline ESL & 2376 & 43,56 & 63,11 & 6,08 & 5,24 & 12,78 & 0,17451 \\
\hline
\end{tabular}

\section{DISCUSSION OF RESULTS AND CONCLUSION}

As it can be seen in table 3 , the highest demand for superplasticizer, so that the planned slump could be achieved, was observed in the concrete mix in which partial replacement of fine river aggregate with granulated recycled rubber was performed. It is a logical consequence of reduction of aggregate particles below $0,5 \mathrm{~mm}$, because the replacement of the natural aggregate fraction 0-4 $\mathrm{mm}$ was done by the recycled granulated rubber having fraction $0,5-4 \mathrm{~mm}$. Also, the increase of friction in the concrete mixture is affected by the shape of the grain of the rubber aggregate, which resembles the shape of the crushed aggregate (flat sides, sharp edges). It can also be seen in the table 3 that for each type of concrete mixes, there was an increased demand for superplasticizer if the concretes were microreinforced, more so in case of the concretes with steel fibers. It can be explained by the fact that the fibers provide increased compactness to the concrete and reduce the slump of fresh concrete composite. Owing to the longer and hook ended fibers, the steel fibers reduced slump to a greater extent, so this resulted in the increased demand of superplasticizer so that the required consistency could be achieved. The polypropylene fibers have the capacity to keep a certain amount of water on its surface, but considering the small quantity of used fibers, it cannot be stated that this effect influenced the slump of fresh concrete to a great extent, and thus influenced the quantity of the used superplasticizer.

Based on the test results provided in table 4, it can be concluded that partial replacement of fine river aggregate with recycled granulated rubber to great extent influenced the reduction of density of compacted fresh concrete (amounting to 3,59\% in comparison to the reference concrete). The reason for this is far lower density of recycled granulated rubber $\left(1150 \mathrm{~kg} / \mathrm{m}^{3}\right)$ in comparison to the density of 
fine river aggregate $\left(2630 \mathrm{~kg} / \mathrm{m}^{3}\right)$, as well as somewhat higher percentage of air content in fresh concrete mixture (table 4). The addition of polypropylene fibers, had a negligibly lower effect on the variation of density of compacted fresh concrete. This is to be expected regarding the very small quantity of fibers $\left(0,91 \mathrm{~kg} / \mathrm{m}^{3}\right)$, as well as a small contribution of these fibers to the total amount of air content in fresh concrete mixture (table 4). The addition of steel fibers contributed to small increase of density of compacted fresh concrete, regarding the dosage of these fibers, amounting to $25 \mathrm{~kg} / \mathrm{m}^{3}$ of concrete.

Based on the test results provided in table 4, it can be concluded that the partial replacement of the natural fine aggregated with recycled granulated rubber caused the increase of air content of fresh concrete. This is explained by the fact that in the concrete mixture there is a lack of small particles of $0,5 \mathrm{~mm}$ which could fill the empty space between the coarse aggregate grains, because the replacement of the natural aggregate of fraction 0-4 $\mathrm{mm}$ was performed by the recycled granulated rubber fraction of $0,5-4 \mathrm{~mm}$. Another very important fact is that wetting of the granulated rubber grains is difficult because of the roughness of the grains which was caused by breaking into small pieces and by non-hygroscopic nature of rubber. For the previous reasons, on the occasion of mixing the concrete composite which contains the recycled granulated rubber, slightly higher percentage of air is entrapped in comparison to the reference concrete mixture. The addition of polypropylene and steel fibers had only a small influence on the variation of air content in fresh concrete, which was negligibly increased. This effect was more prominent in case when higher quantity of fibers is added (regardless of their kind and type). By comparing the obtained results, it can be concluded that the concretes reinforced by the polypropylene fibers have slightly higher air content in comparison to the concretes with steel fibers. This is logical regarding that the number of polypropylene fibers in a unit of volume is considerably higher in respect to the steel fibers.

Partial replacement of fine river aggregate with granulated recycled rubber contributed to the significant decrease of compressive strength. Analyzing the obtained results in the table 5, it was stated that in case of the concretes with rubber, the decrease of compressive strength in respect to the reference concrete is $23,48 \%$ at the age of concrete of 28 days, i.e. $28,10 \%$ at the age of 90 days. As for the reinforcement of concrete with microfibers, it can be said that both polypropylene and steel fibers provided a small contribution to the increase of compressive strength. Based on the test results, it can be seen that slightly more favorable effect was achieved using short hook ended steel fibers. As for the polypropylene fibers, the fibrillated ones provided slightly higher compressive strengths in respect to the monofilament ones. The polypropylene monofilament fibers contribution to the increase of compressive strength amounted to $0,84 \%(3,84 \%)$, while the contribution of the polypropylene fibrillated fibers amounted to $2,11 \%(4,75 \%)$ at the concrete age of 28 (90) days. AS for the hook ended steel fibers, the short fibers contribution to compressive strength amounted to $0,63 \%(5,29 \%)$, while the long fibers contribution amounted to $3,18 \%(3,65 \%)$ at the age of concrete of 28 (90) days.

As it is already known, the addition of fibers to the concrete should primarily provide higher tensile strength of concrete, as it was confirmed in this paper based on the test results presented in table 5. In a similar way as in case of the compressive strength, the flexural strength is influenced by type and geometry of applied fibers, as well as content of recycled rubber in concrete. Also, as in case of the concretes made with partial replacement of fine river aggregate with recycled granulated rubber, the obtained values of flexural strength were expectedly lower than in the case of the reference concrete. It is explained by the fact that the adhesive bond between the cement stone and recycled rubber grains is weaker than the bond between the stone aggregate and cement stone, by the increased air content entrapped during mixing and placing of concrete, as was demonstrated by the test results of the air content in fresh concrete, table 4. Partial replacement of the river aggregate with the granulated recycled rubber in concrete contributed to the drop of flexural strength in the amount of $16,90 \%$. As for the reinforcing of concrete with microfibers, the polypropylene monofilament fibers contributed to the flexural strength increase of $6,34 \%$, while the polypropylene fibrillated fibers contribution amounted to $7,75 \%$. In case of the steel fibers with hooked ends, the short fibers contributed to the increase of flexural strength of $9,51 \%$, while the long fibers contribution amounted to $7,04 \%$.

Partial replacement of fine river aggregate with granulated recycled rubber in concrete contributed to the decrease of splitting tensile strength of $22,08 \%$. As for the reinforcement of concrete with micro-fibers, the polypropylene monofilament fibers contributed to the increase of splitting tensile strength in the amount of $13,80 \%$, while the contribution of polypropylene fibrillated fibers amounted to $12,53 \%$. In case of the hook ended steel fibers, the short fibers contributed to the increase of splitting tensile strength in the amount 
of $15,50 \%$, while the long fibers contribution amounted to $11,32 \%$.

Partial replacement of fine river aggregate with the granulated recycled rubber contributed to the considerable decrease of the wear value, i.e., to the considerable increase of wear grinding resistance. In comparison to the reference concrete, in case of recycled rubber concrete, the wear value was reduced for $48,84 \%$. The value of wear is to a good extent influenced by the density of the rubber granulate which is more than twice lower than the density of the stone aggregate, i.e. the cement paste. Also it is not contentious that for this abrasion method, the rubber granulate is more resistant than the stone aggregate, because of its capacity to retain the elastic property during the longer time period of stress. The friction forces occurring during abrasion, on the contact between the abrasive surfaces are not sufficiently high to tear out the rubber granules from the concrete composite, figure 5 . As it can be seen in the figure, the surface of concrete sample is flat, the rubber granulate is homogenously distributed in concrete mass, and there are no traces that there was tearing out of the rubber granules. Such arrangement of rubber granules on the surface of the concrete sample prevents accelerated abrasion of cement stone and river aggregate grains, and for that reason the rubber concrete has an increased wear grinding resistance.

As for the micro-reinforcing of concrete, the polypropylene monofilament fibers contributed to the increase of wear ginding resistance for $9,01 \%$, while the polypropylene fibrillated fiber contribution amounted to $4,44 \%$. In case of the steel fibers with hooked ends, the short fibers contributed to the increase of wear grinding resistance to strength in the amount of $8,15 \%$, while the long fibers contribution amounted to $10,63 \%$. It must be emphasized here that the value of wear grinding resistance was to a great extent influenced by the arrangement of micro-reinforcement in the concrete composite. Namely, as the polypropylene fibers are smaller and more numerous in comparison to the steel ones, the distribution of those fibers in the concrete composite is more homogenous in terms of quantity and direction of fibers. This is of particular importance for the surface parts of concrete sample on which the wear grinding resistance is tested. The steel fibers are far more resistant to abrasion in comparison to concrete, so the addition of these fibers to concrete in an optimal amount increases the resistance of concrete to wear grinding. The opposite effect may occur, when the excessive dosage of steel fibers causes reduction of abrasion resistance [20]. The basic reason for reduction of wear grinding resistance in this case is removal of fibers from the surface of concrete.

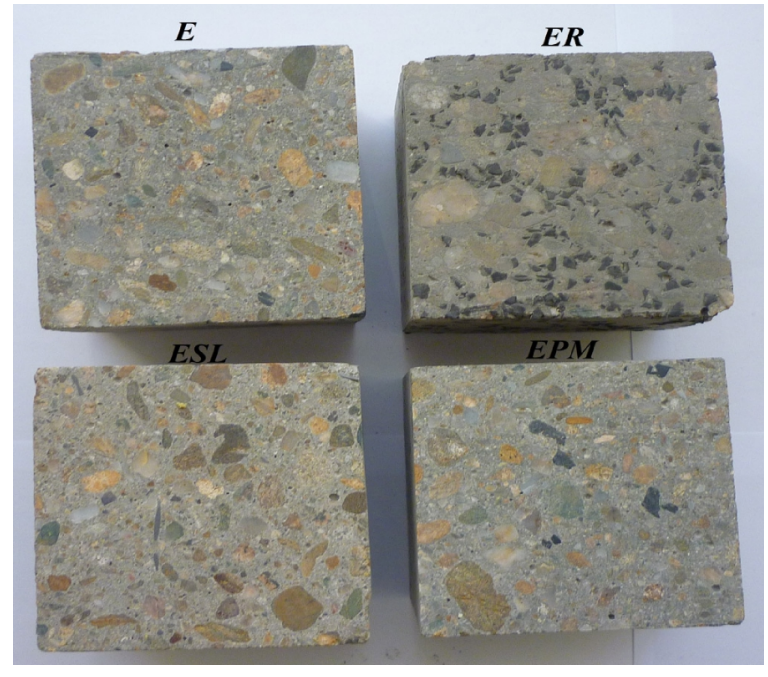

\section{Figure 5 - Appearance of the concrete surface after abrasion resistance testing}

Partial replacement of fine river aggregate with the granulated recycled rubber contributed to the significant reduction of abrasion under the action of water/sand jet, i.e. to the considerable increase of hydro-abrasive resistance of concrete. In comparison to the reference concrete, in case of the recycled rubber concretes, the abrasion was reduced for $33,51 \%$. The similar situation was in the case of testing of concrete wear grinding resistance, whereby the reduction of wear of concrete samples with rubber in respect to the corresponding reference concretes was slightly higher, and amounted to $48,84 \%$.

The action of waterborne sand grains (abrasive) on the concrete slab has an impact characters, due to hydro-abrasion. It is known that rubber is a good absorber of impact load, so the presence of rubber granules in concrete composite contributes to the increase of its elasticity which directly increases capacity to absorb the solid particle impact. Most of the solid particle energy is spent of the elastic deformation during impact, while only a small part creates a plastic deformation, i.e. degradation of surface parts of the concrete specimen. In figure 6 is presented the concrete specimen of ER batch after testing of hydro-abrasive resistance of concrete.

As it can be seen in figure 6 , the damage on the concrete slab was formed after wearing off and separation of the parts of cement matrix and coarse grains of aggregate, and due to extraction 
of fine grains of the aggregate from the cement matrix. In practical terms, the grains of rubber cannot be broken due to the hydro-abrasion action, it is more probable that they would be torn out from the cement matrix due to exceeding of adhesion forces. Also, on the surface of the concrete sample, it can be observed that the rubber granules are left bare and free from the cement matrix, which is not the case with the river aggregate. It can be explained by the lower adhesion force of the bond between the cement matrix and rubber granules in respect to the adhesion force between the cement matrix and river aggregate grains.

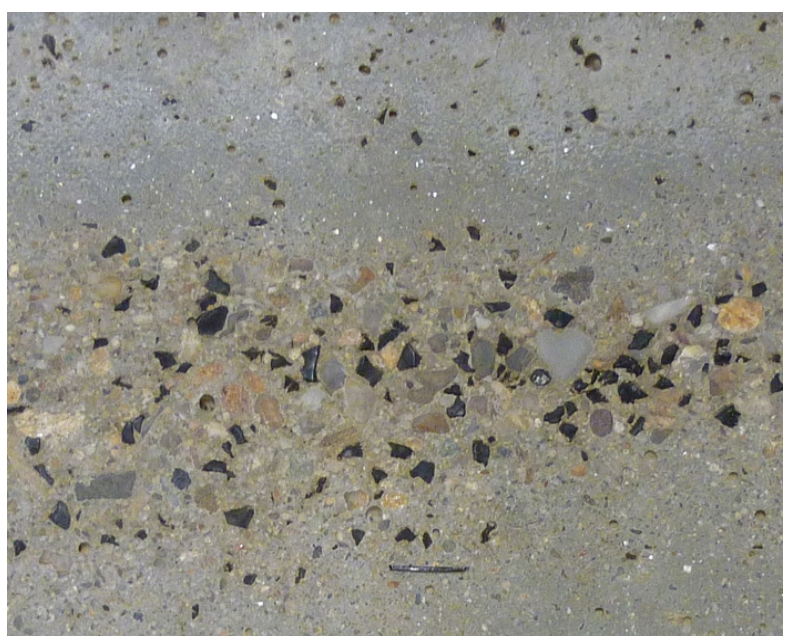

Figure 6-Appearance of the surface of the sample of $E R$ batch after testing of hydro-abrasion resistance

As it can be seen in figure 6 , the damage on the The addition of steel hook ended fibers had a very little effect on its hydro-abrasion resistance. The short steel fiber, i.e. the steel fiber with the higher aspect ratio contributed to the reduction of the hydro-abrasion rate by volume $\left(E_{R, V}\right)$ of concrete for $4,33 \%$ in respect to the reference concrete, while the long steel fibers contributed the reduction for $2,03 \%$.

Namely, the phenomenon of extraction of fibers from the cement matrix occurs in concretes reinforced by steel fibers (in the concrete case, the steel hook ended fibers $\mathrm{ZS} / \mathrm{N}-0,50 \times 30 \mathrm{~mm}$ and $\mathrm{ZS} / \mathrm{N}-1,05 \times 50 \mathrm{~mm})$. The attack angle between the water/sand jet mixture and the concrete slab and orientation of steel fibers in the concrete composite are very important in the process of abrasion of concrete reinforced with steel fibers. After the finished testing of hydro-abrasion resistance of concrete and macroscopic examination of the surface of micro-reinforced concrete, it could be established whether there was pulling out or cutting of the fibers due to the action of solid particles in water, figure 7. This phenomenon most often occurs when solid particles hit the slab perpendicularly to the direction of fibers and at a low impact angle (around 15 degrees).

In case the impact angle of abrasion particles on the concrete surface is $45-60^{\circ}$ and the steel fibers are not placed parallel to the abrasion surface, the so called "shadow zone" is formed immediately behind the exposed fiber, as a result of the action of the abrasive normally to the longitudinal axis of the fiber. This area of cement matrix is protected from the influence of the abrasive, because the total energy of impact is absorbed with steel fibers, which repel the abrasive particles.

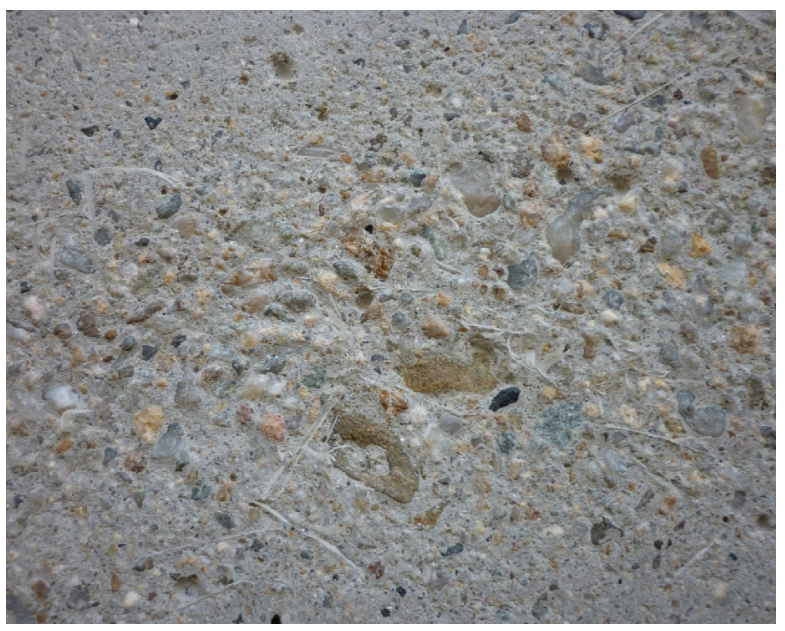

Figure 7 - The surface of the concrete sample micro-reinforced with steel fibers $\mathrm{ZS} / \mathrm{N}$ 0,50x30mm: 1 - fiber indentation, 2 - fiber cutting

The range of the "shadow zone" depends on the length and rigidity (aspect ratio) of the used steel fibers and the position of fibers in the cement matrix in respect to the damaged surface. The presence of the "shadow zone" was observed in both kinds of steel fibers. Delamination of rigid steel fibers from the cement matrix occurred due to the powerful impacts of solid waterborne particles. The steel fibers sustained considerable plastic deformation, causing "grooving" of cement matrix in the contact zone with surface of the fiber, figure 8 . After cutting of the fiber, the cement paste from the "shadow zone" is removed by the abrasion particles. The phenomenon of the "shadow zone" was observed on the surfaces of the samples of both types of fibers (short and long). The size of the "shadow zone" depends on the impact angle of abrasion particles on the concrete slab and the direction of placing of steel fibers in respect to the tested surface. In this paper, the impact angle was 45 degrees, while in actual conditions, the impact angle ranges between 0 and 90 degrees. 
a)

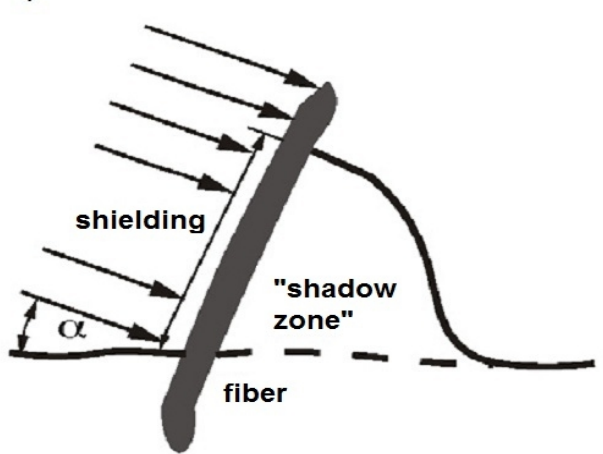

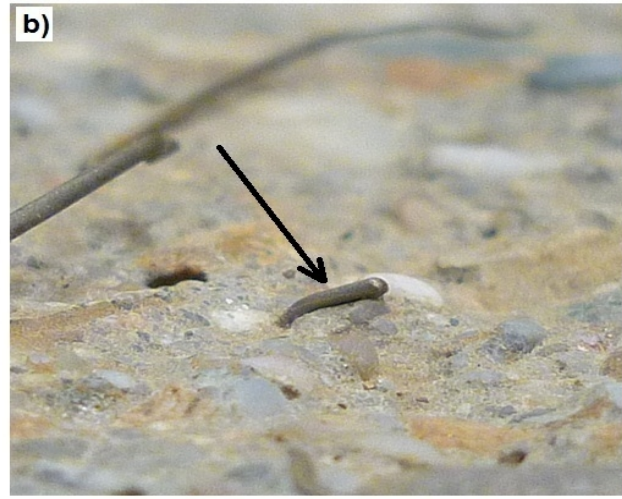

Figure 8 - Formation of the "shadow zone" in the micro-reinforced concrete:

(a) schematics of "shadow zone" formation, (b) image of the formed "shadow zone"

The decrease of the hydro-abrasion resistance of concrete with long steel fibers in comparison to the reference concrete obtained in this research can be explained by the high rigidity of the steel fibers (low value of aspect ratio), which is the reason for fiber delaminating from the cement matrix. The rigid fibers caused grooving of the cement matrix in the contact zone as a result of the plastic deformation due to the impact of the solid waterborne particles. This facilitated an accelerated hydro-abrasion of cement matrix in comparison to the samples of the reference concrete.

The conclusion regarding abrasion of concrete reinforced with steel fibers is that addition of the steel fibers to concrete does not significantly contribute to increase of its hydro-abrasion resistance, while it does significantly contribute to increase of the wear grinding resistance.

As the test results in the table 5 show, addition of the polypropylene fibers contributed a considerable increase of its resistance to hydroabrasion, whereby the better effect was achieved by using the fibrillated fibers of polypropylene fibers. This effect, in case of the addition of the fibrillated polypropylene fibers, is reflected in the $17,20 \%$ reduction of the hydro-abrasion rate by volume, in comparison with the reference concrete. In case of the addition of the monofilament fibers, this reduction is $13,01 \%$. These data indicate that aspect ratio and number of fibers did not to a great degree affect the hydro-abrasion resistance of the concrete reinforced with the polypropylene fibers. Possibly, the small difference can be explained by the mutual cross-wise connections of the fibrillated fibers, meaning that when the abrasive from water acts on the surface on concrete, more fibers are activated in reception of the impact load, which is not the case with the monofilament fibers.

The comparative analysis of testing results of the degree of hydro-abrasive erosion per volume of micro-reinforced concretes, showed the decrease of hydro-abrasive resistance of the concrete reinforced with steel fibers in comparison with the concrete reinforced with the polypropylene fibers. The increase of hydro-abrasive resistance reinforced with the polypropylene fibers is related to the better adhesion of these fibers with cement matrix in respect to the steel fibers.

The polypropylene fibers used in this research are several times bigger than the average size of cement grain, but in comparison with eth steel fibers, they are more flexible, and form the compact structure together with the cement matrix. The polypropylene fibers have very low water absorption capacity. In addition, the surface tension of polymer materials is usually lower than the surface tension of water. In the research [31] it is stated that in the contact zone of the polypropylene fiber cement matrix, there is no portlandite, so there is no potential for the local increase of water/cement ratio, and consequently for reduction of adhesion, which is not case with the concretes having the steel fibers.

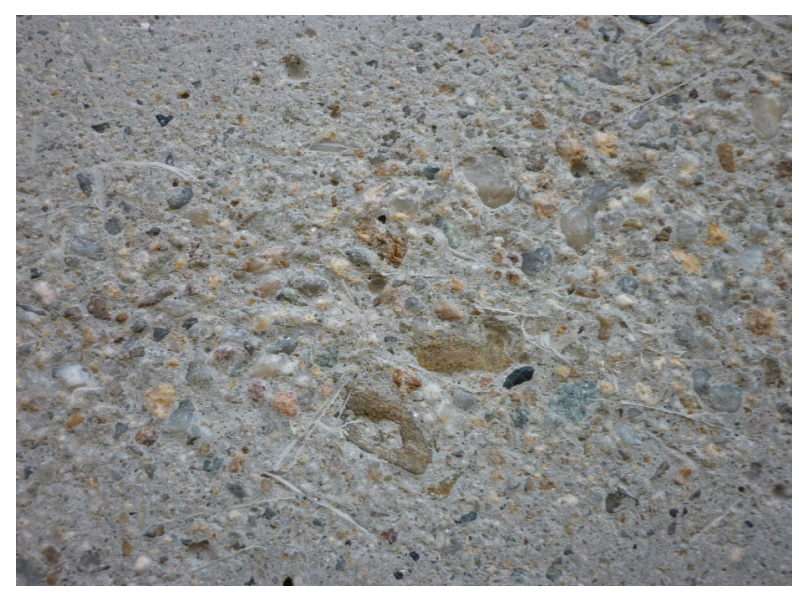

Figure 9 - Surface of the sample of concrete microreinforced with polypropylene fiber 
As it can be seen in figure 9, the polypropylene fibers are broken as a result of impact of solid abrasive particles on the concrete surface, which is confirmed by their good adhesion with the cement matrix.

The conclusion is that the addition of the polypropylene fibers to concrete contribute to the considerable improvement of its hydro-abrasive resistance, as well as to the improvement of the wear grinding resistance and of other physical and mechanical performances of concrete (table 5), so this type of concrete can be used not only for making of the structural elements of buildings exposed to abrasion action, but other structural elements as well, where there are special requirements in terms of bearing capacity, stability and durability.

\section{Acknowledgements}

The work reported in this paper is a part of investigation within the research project TR 36017 „Utilization of by - products and recycled waste materials in concrete composites in the scope of sustainable construction development in Serbia: investigation and environmental assessment of possible applications" supported by Ministry for Science and Technology, Republic of Serbia. This support is gratefully acknowledged.

\section{REFERENCES}

[1] P.Laplante, P.Aitcin, D.Vezna (1991) Abrasion resistance of concrete, ASCE J Mater Civil Eng, 3(1), 19-28.

[2] P.Mehta, P.J.M.Monteiro (2006) Concrete structure, properties, and materials, third ed., Copyright (c) 2006 by The McGraw-Hill Companies, Inc.

[3] K.Hadchti, R.Carrasquillo (1988) Abrasion resistance and scaling resistance of concrete containing fly ash, research report, University of Texas at Austin, p. 481-83.

[4] H.Binici, O.Aksogan, E.Gorur, H.Kaplan, M.Bodur (2009) Hydro-abrasive erosion of concrete incorporating ground blast-furnace slag and ground basaltic pumice, Constr. Build. Mater, 23, 804-811.

[5] Y.W.Lui (2007) Improving the abrasion resistance of hydraulic-concrete containing surface crack by adding silica fume, Constr Build Mater, 21, 972-977.

[6] R.Siddique, J.Khatib (2010) Abrasion resistance and mechanical properties of high-volume fly ash concrete, Mater Struct, 43, 709-718.

[7] S.Hui Choi, J.Bolander (2012) A topology measurement method examining hydraulic abrasion of high workability concrete, KSCE J Civ Eng, 16(5), 771-778.

[8] N.Ristic, Z.Grdic, G.Toplicic-Curcic (2012) Influence of fly ash on the hydroabrasion-erosion resistance on concrete in hydraulic structures, Proceedings of the $12^{\text {th }}$ International Scientific Conference
"Planning, design, construction and renewal in the civil engineering", Novi Sad, Serbia, p. $658-665$.

[9] E.Horszczaruk (2002) Hydro-abrasive erosion of high performance fiber-reinforced concrete, Wear, 267, 110-115.

[10] X.G.Hu, A.W.Momber, Y.G.Yin (2002) Hydroabrasive erosion of steel-fibre reinforced hydraulic concrete, Wear, 253, 848-854.

[11] X.G.Hu, A.W.Momber, Y.Yin, H.Wang, D.Cui (2004) High-speed hydrodynamic wear of steel-fibre reinforced hydraulic concrete", Wear, 257, 441450.

[12] N.Ristic, Z.Grdic, G.Toplicic-Curcic, I.Despotovic (2011) Hydro-abrasive resistance of micro-reinforced concrete with steel and polypropylene fibres, International symposium about research and application of modern achievements in civil engineering in the field of materials and structures, Tara, Serbia, p. $125-134$.

[13] Chernov, H.Zlotnikov, M.Shadalov (2006) Structural synthetic fiber-reinforced concrete. Experience with marine applications, Concr Int, 8, 56-61.

[14] Z.Grdic, G.Curcic, N.Ristic, I.Despotovic (2012) Abrasion resistance of concrete micro-reinforced with polypropylene fibers, Constr Build Mater, 27, 305-312.

[15] H.Toutanji (1996) The Use of Rubber Tire Particles in Concrete to Replace Mineral Aggregates", Cem Concr Compos, 16, 135-139.

[16] J. Šušteršič (2004) Abrazijsko odporni betoni, 11. slovenski kolokvij o betonih - Gradnja z betoni visokih zmogljivosti, Zbornik gradiv in referatov, Ljubljana, Slovenia, p. 41-48.

[17] T.Yen, T.H.Hsu, Y.W.Lui, S.H.Chen (2007) Influence of class $\mathrm{F}$ ash on the abrasion-erosion resistance of high-strength concrete, Constr Build Mater, 21, 458-63.

[18] Y.W.Lui, T.Yen, T.H.Hsu (2006) Abrasion erosion of concrete by water-borne sand, Cem Concr Res, 36, 1814-20.

[19] S.Yazici, G.Inan (2006) An investigation on the wear resistance of high strength concretes", Wear, 260,15-618.

[20] C.Yalçınkaya, J.Sznajder, A.Beglarigale, O. Sancakoğlu, H.Yazıcı (2014) Abrasion resistance of reactive powder concrete: the influence of water-tocement ratio and steel micro-fibers, Adv. Mat. Lett., 5(6), 345-351

[21] E.Horszczaruk (2004) Abrasion resistance of high strength fibre reinforced concrete", in: Fibre-Reinforced Concretes BEFIB'2004, RILEM Publications S.A.R.L., vol. 1, Bagneux, p. 257-266.

[22] T.Naik, S.Singh, B.Ramme (1998) Mechanical properties and durability of concrete made with blended fly ash, ACl Materials Journal, 95, 454462.

[23] K.Sobolev (2004) The development of a new method for the proportioning of high performance concrete mixtures, Cement \& Concrete Composites, 26, 901-907. 
[24] P.Higgins, M.Kurtovich (2003) Repairing critical assets using high performance calcium aluminate cements, in: M-NZ Concrete Society Conference, Wairakei, October, p. 23-28.

[25] M.A.Tas, A.I'lki, M.Yerlikaya (2002) Mechanical behaviour of steel fibre reinforced concrete used in hydraulic structures, in: HYDRO, International Conference of Hydropower and Dams, 4-7 October, Kiris-Antalya, p.159-166.

[26] P.W.Chen, F.Xuli, D.D.Chung (1997) Microstructural and mechanical effects of latex, methylcellulose, and silica fume on carbon fiber reinforced cement, ACl Materials Journal, 94, 147-155.

[27] V.Chernov, H.Zlotnikov, M.Shadalov (2006) Structural synthetic fiber-reinforced concrete. Experience with marine applications, Concrete International, 8, 56-61.
[28] M.Sadegzadeh, R.Kettle, V.Vassou (2001) The influence of glass, polypropylene and steel fibers on the physical properties of concrete, Concrete, 35 , 12-22.

[29] F.Jacobs (2003) Betonabrasion im Wasserbau, Beton, 1, 16-23.

[30] J.E.McDonald (2000) Evaluation of materials for repair of erosion damage in hydraulic structures, durability of concrete, in: Proceedings Fifth International Conference Barcelona, ACl SP-192, vol. II, Farmington Hills, p. 887-898.

[31] W.Pichor, J.Dyczek (1997) Early formation on the interfacial zone in FRC with PAN fibers, Proc. Int. Symposium Brittle Matrix Composites 5, PAN, Warsow, p. 74-78.

IZVOD

\section{ABRAZIVNA OTPORNOST BETONA SPRAVLJENOG SA MIKROVLAKNIMA I RECIKLIRANOM GRANULISANOM GUMOM}

Trajnost betonskih građevinskih konstrukcija u najvećoj meri zavisi od otpornosti njihovih površina prema mehaničkom habanju. $U$ radu su prikazani rezultati eksperimentalnog istraživanja performansi u svežem i očvrslom stanju različitih vrsta betona, kao i uporedna analiza otpornosti prema habanju brušenjem $i$ hidro-abrazivne otpornosti betona.. Za potrebe istraživanja napravljeno je šest serija betona: etalon beton $(E)$, beton sa delimičnom zamenom sitnog rečnog agregata recikliranom granulisanom gumom (ER), dve serije betona sa dodatkom polipropilenskih vlakana (monofilamentnih (EPM)i fibriliranih (EPF)) $i$ dve serije betona sa dodatkom čeličnih vlakana sa ojačanim krajevima (kraća - dužine $30 \mathrm{~mm}$ (ESS) i duža - dužine $50 \mathrm{~mm}$ (ESL)). Utvrđeno je da dodatak mikroarmature ili reciklirane granulisane gume doprinosi povećanju otpornosti betona prema habanju brušenjem i hidro-abrazivne otpornosti. Postoji razlika u otpornosti prema habanju betona u zavisnosti od metode ispitivanja.

Ključne reči: beton, reciklirana granulisana guma, polipropilenska vlakna, čelična vlakna, otpornost prema habanju brušenjem, hidro-abrazivna otpornost

Naučni rad

Rad primljen 13.06.2015.

Rad prihvaćen 19.08.2015.

Rad je dostupan na sajtu: www.idk.org.rs/casopis 